\title{
Survey of bovine colostrum quality and hygiene on northern Victorian dairy farms
}

\author{
A. J. Phipps, ${ }^{* 1}$ D. S. Beggs, $†$ A. J. Murray, ${ }^{*}$ P. D. Mansell, $†$ M. A. Stevenson, $\dagger$ and M. F. Pyman $\dagger$ \\ ${ }^{*}$ Rochester Veterinary Practice, 72 Lowry Street, Rochester, 3651, Australia \\ †Faculty of Veterinary and Agricultural Sciences, University of Melbourne, Werribee, 3030, Australia
}

\begin{abstract}
One of the major challenges for dairy producers is to produce, harvest, and store high-quality colostrum and feed it to their replacement heifer calves. Limited published data are available in Australia regarding the relationship between colostrum management, hygiene, and quality. The objectives of this study were to investigate (1) the colostrum storage and handling practices carried out on farm; (2) the immunoglobulin concentration and bacterial composition of colostrum being fed to replacement dairy heifer calves; (3) the percentage of colostrum being fed to replacement dairy heifer calves that meet industry recommendations; and (4) risk factors for bacterial contamination of colostrum. The study was carried out on 24 dairy farms located near Rochester, Victoria, Australia. Two hundred forty colostrum samples were collected (10 samples per farm). Each farm harvested and stored first-milking colostrum under normal farm conditions. A 10-mL sample of the colostrum was collected in a sterile container immediately before feeding, and a Brix refractometer reading was taken. The samples were then frozen at $-4^{\circ} \mathrm{C}$ and submitted for bacterial concentration analysis. Fiftyeight percent of colostrum samples met the recommended industry standard of a total plate count (TPC) of $<100,000 \mathrm{cfu} / \mathrm{mL}$, and $94 \%$ of colostrum samples met the recommended industry standard of total coliform count (TCC) of $10,000 \mathrm{cfu} / \mathrm{mL}$. However, when all the current industry recommendations for TPC, TCC, and Brix refractometer percentage for colostrum quality were considered, only $23 \%$ of the samples met all standards. These findings demonstrate that a large number of calves were at risk of receiving colostrum of poor quality, with high bacterial loads that may have interfered with the acquisition of transfer of passive immunity and affected calf health. Further investigation is required to identify the farm-specific factors that
\end{abstract}

Received March 22, 2016.

Accepted July 27, 2016.

${ }^{1}$ Corresponding author: ashphipps87@gmail.com may influence the level of bacterial contamination of colostrum. Recommendations as a result of this study include refrigeration of excess colostrum shortly (within $1 \mathrm{~h}$ ) after collection and thorough disinfection of the calf feeding apparatus before use.

Key words: colostrum management, dairy calf, total plate count, coliform

\section{INTRODUCTION}

The management and feeding of high-quality colostrum is important for the acquisition of transfer of passive immunity (TPI) and has been well investigated. Successful TPI has short-term effects for reducing the risk for morbidity and mortality in the preweaning period and long-term positive effects on calf health and future production (Bush and Staley, 1980; DeNise et al., 1989; Wells et al., 1996; Robison et al., 1988; Donovan et al., 1998; Quigley and Drewry, 1998; Faber et al., 2005).

The timing of feeding colostrum relative to birth and the colostral IgG concentration are widely considered the factors that have the greatest influence on the TPI and calf health (Arthington et al., 2000). Bacteria in colostrum that are derived either by shedding from the mammary gland or from environmental contamination are believed to either bind free IgG in the intestinal lumen or block the uptake and thus transport of IgG into the enterocyte (James et al., 1977, 1981; James and Polan, 1978; Staley and Bush, 1985). Bacteria in the colostrum could affect the immunoglobulins available for transport into the calf's enterocytes, possibly interfering with the TPI (Elizondo-Salazar and Heinrichs, 2009). Few field studies have quantified the effect of feeding colostrum with high bacterial counts and the association with immunoglobulin absorption in calves. Two recent studies have reported a deleterious association between bacteria counts in colostrum and immunoglobulin absorption (Poulsen et al., 2002; Johnson et al., 2007).

Stewart et al. (2005) identified control points for bacterial contamination of colostrum from harvest- 
ing to feeding of colostrum to calves. They found the harvesting process to be a significant control point for contamination of colostrum. Bacteria may be introduced into the colostrum from the teat skin, milking cup liners, hoses, or buckets.

A wide search of the current available literature revealed very limited data regarding the percentage of colostrum being fed to replacement dairy calves on Australian dairy farms that meets the industry recommendations on quality and hygiene. The objectives of this study were to investigate (1) colostrum storage and handling practices carried out on farm; (2) the immunoglobulin concentration of colostrum being fed to replacement dairy heifer calves; (3) the bacterial composition of colostrum being fed to replacement dairy heifer calves; (4) the percentage of colostrum being fed to replacement dairy heifer calves that meets industry recommendations for both immunoglobulin concentration and bacterial composition; and (5) risk factors for bacterial contamination of colostrum.

\section{MATERIALS AND METHODS}

\section{Study Population}

The source population for this study comprised commercial dairy herds in the Rochester district of Victoria, Australia. The eligible population was herds whose herd managers used the services of the Rochester Veterinary Practice and routinely supplemented replacement heifers with colostrum once they had been brought into their calf rearing facilities. In May and June 2014, herd managers from eligible herds were invited to take part in the study. The study population comprised the herds whose herd managers had agreed to undertake the colostrum sampling protocols defined as part of the study design. Fresh colostrum samples were collected from 24 dairy herds that calved down a proportion of their cows between July 15 and August 31, 2014.

\section{Sample Collection and Storage Process}

The study start date was the planned start of calving date for spring-calving cows in each study herd. During the first visit to a study farm, a short questionnaire on general practices was completed with the herd manager or employees responsible for feeding colostrum to replacement heifer calves.

On each farm, colostrum was harvested according to normal farm practices and stored at either ambient temperature, refrigerated, or frozen for a period of time before being fed to a calf or calves. A 10-mL sample of colostrum was collected by the investigator into a sterile container at the time the colostrum was offered to a calf or calves directly from the feeding apparatus used to feed the calf or calves colostrum. A Brix refractometer reading was taken at the time of sampling from each of the samples, using a commercially available Brix refractometer (Brix TE-RM32B with Automatic Temperature Compensation from $10^{\circ} \mathrm{C}$ to $30^{\circ} \mathrm{C}$, Brix range 0-32\%, Test-Equip Pty Ltd., Dandenong South, Victoria, Australia). Further information specific to the individual sample was collected at the time of sampling including the source (dam, another herd mate, or pooled); storage method (ambient temperature, refrigeration, or freezing); container used to store the colostrum (plastic, metal, other, and lid or no lid); duration of storage; feeding apparatus cleaning or disinfection practices; and the handling of the colostrum before sampling.

The colostrum samples were immediately frozen at $-4^{\circ} \mathrm{C}$. This process was repeated for 10 samples on each of the 24 study farms during the 4 -wk period following planned start of calving date.

\section{Colostrum Evaluation Process}

All frozen colostrum samples were submitted in batches to a local laboratory (Gribbles Veterinary Pathology, Melbourne, Victoria, Australia) where the total plate count (TPC) and the total coliform count (TCC) for each sample was determined. The TPC results were reported as the number of colony-forming units per milliliter $(\mathrm{cfu} / \mathrm{mL})$ and categorized as no growth, $<10,000 \mathrm{cfu} / \mathrm{mL}, 10,000$ to $100,000 \mathrm{cfu} / \mathrm{mL}$, and $>100,000 \mathrm{cfu} / \mathrm{mL}$. The TCC results were reported as the number of cfu per milliliter and categorized as no growth, $<1000 \mathrm{cfu} / \mathrm{mL}, 1,000$ to $10,000 \mathrm{cfu} / \mathrm{mL}$, and $>10,000 \mathrm{cfu} / \mathrm{mL}$.

\section{Statistical Analysis}

Statistical analyses were performed using IBM SPSS Statistics 2013 for Windows, Version 22.0 (IBM Corp. Armonk, NY). Descriptive statistics were carried out to document the number of herd managers giving a response for each of the questions with ordinal or nominal outcomes. For continuous variables, the mean, standard deviation, and minimum and maximum values were calculated.

Responses to questions in the questionnaire were either binary (e.g., yes or no) or continuous [e.g., volume (L) of colostrum fed to calves]. Herd size, defined as the number of cows in the milking herd midway through the milking season, was categorized into $<300$ cows and $\geq 300$ cows.

A binary logistic regression model was developed to identify characteristics of colostrum harvesting, stor- 
age, and feeding that were associated with TPC and TCC (expressed as a dichotomous outcome; i.e., above or below a defined threshold). Associations between each of the hypothesized explanatory variables and the outcome of interest (TPC for the first analysis and TCC for the second) were computed using the odds ratio. Explanatory variables with associations significant at the $P<0.25$ level (2-sided) were selected for multivariable modeling.

Each of the explanatory variables that were associated with the outcome (TPC or TCC) at $P<0.25$ were entered into the logistic regression model. Explanatory variables that were not statistically significant $(P>$ 0.05 ) were removed from the model one at a time, beginning with the least significant, until the estimated regression coefficients for all explanatory variables retained were significant at an $\alpha$ level of $<0.05$ and significant $(P<0.05)$. A $P$-value of $\leq 0.09$ was considered a trend toward significance.

To account for hierarchical structure of the data (i.e., colostrum samples clustered within herds), a herd-level random effect term was included in the model. The prediction intervals of the random effect for each herd were plotted on a caterpillar plot, for the TPC mixed effects model. All regression analyses were carried out using Stata version 13 (StataCorp, 2013).

\section{RESULTS AND DISCUSSION}

A total of 240 colostrum samples, from 24 farms, were obtained and analyzed in this study. Ten herds had $<300$ cows, and 14 herds had $\geq 300$ cows. This study is the first to describe the quality of colostrum in terms of both IgG concentration and bacterial load being fed to replacement heifer calves on Australian dairy farms. Although the present study is limited in size and the data presented may not be representative of the colostrum being fed to all replacement dairy heifers throughout Australia, the herds enrolled in the study are believed to be broadly representative of commercial dairy herds in northern Victoria.

\section{Colostrum Quality}

Figure 1 shows the distribution of Brix refractometer readings for the colostrum samples. The current Australian dairy industry recommendation is to use colostrum with a Brix refractometer reading of at least $22 \%$ (Dairy Australia, 2011). In this study, only $46.7 \%$ of colostrum samples satisfied this criterion (Table 1). The percentage of colostrum samples from previous studies that were considered to be of good quality ranged from 50 to $92 \%$ (Dinsmore and Skidmore, 2008; Bielmann et al., 2010; Quigley et al., 2013; Bartier et al., 2015;
Table 1. Number of samples distributed across Brix percentage and total plate count (TPC) and total coliform count (TCC) concentrations

\begin{tabular}{llc}
\hline Item & Category & No. $(\%)$ \\
\hline Brix percentage & $<22 \%$ & $128(53.3)$ \\
& $>22 \%$ & $112(46.7)$ \\
TPC $(\mathrm{cfu} / \mathrm{mL})$ & Total & $240(100)$ \\
& No growth & $14(6)$ \\
& $<10,000$ & $58(24)$ \\
& $10,000-100,000$ & $68(28)$ \\
TCC $(\mathrm{cfu} / \mathrm{mL})$ & $>100,000$ & $100(42)$ \\
& Total & $240(100)$ \\
& No growth & $152(63)$ \\
& $<1,000$ & $60(25)$ \\
& $1,000-10,000$ & $12(5)$ \\
& $>10,000$ & $16(6)$ \\
& Total & $240(100)$ \\
\hline
\end{tabular}

Morrill et al., 2015). However, it should be noted that not all of these studies used the Brix cutoff level of $22 \%$. The mean Brix percentage was lower, $20.78 \%$, than previously reported means of $26.1 \%$ (Bielmann et al., 2010), 24.3\% (Bartier et al., 2015), 23.8\% (Quigley et al., 2013), and 21.24\% (Morrill et al., 2015). In the current study, the Brix percentage range was similar to previously reported ranges of 13.5 to $32 \%$ (Bielmann et al., 2010), 12 to $32 \%$ (Quigley et al., 2013), and 10.5 to $28.6 \%$ (Morrill et al., 2015). Interestingly, in the Bartier et al. (2015) study, the range was much greater, 10.4 to $52.6 \%$.

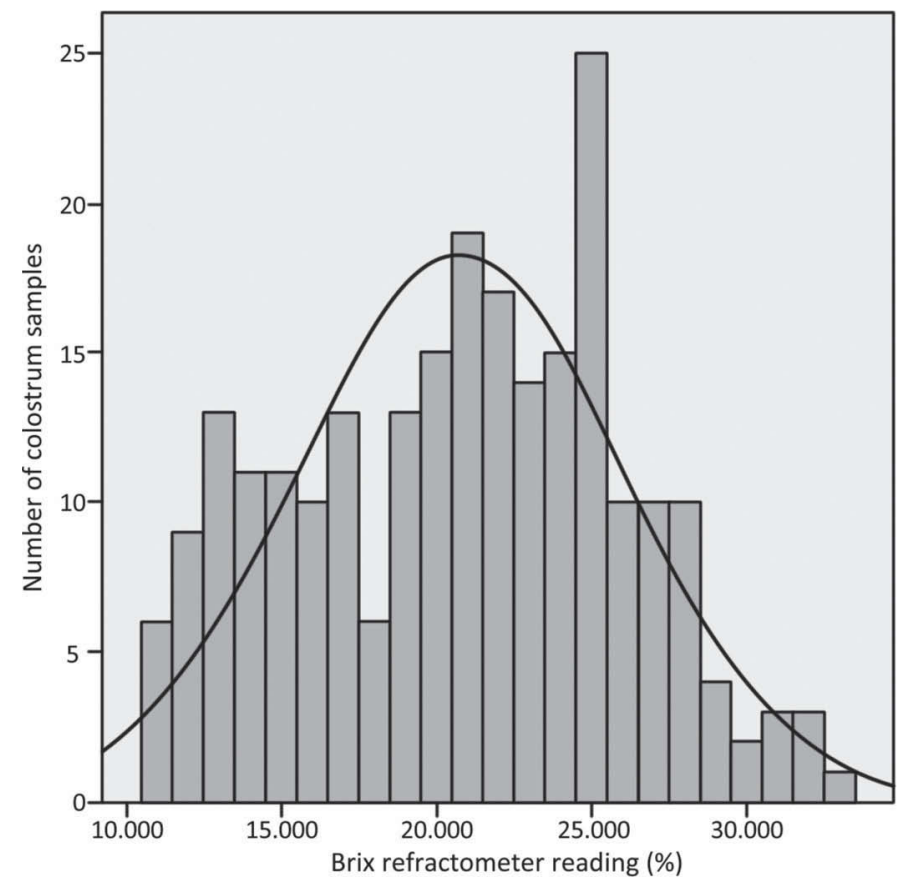

Figure 1. Frequency histogram showing the distribution of Brix refractometer readings for the 240 colostrum samples. 
A secondary measure of colostrum quality is the bacterial load. Adopting the US standards of bacterial contamination of colostrum, colostrum should contain $<100,000 \mathrm{cfu} / \mathrm{mL}$ for TPC and $<10,000 \mathrm{cfu} / \mathrm{mL}$ for TCC at the time it is fed to the calf (McGuirk and Collins, 2004; Stewart et al., 2005). Table 1 details the number of samples distributed across TPC and TCC.

In this study, most samples met the industry recommendation in terms of TCC $(94 \%, \mathrm{n}=224)$. However, only $58 \%(\mathrm{n}=140)$ of the colostrum samples met the recommendations in terms of TPC (Table 1). These findings are similar to those of the study by Morrill et al. (2012), in which $54.8 \%$ met the recommendations in terms of TPC, and a slightly lower result than the study by Fecteau et al. (2002), in which $64.1 \%$ met the recommendations in terms of TPC. When industry recommendations in terms of TPC, TCC, and Brix refractometer readings for the overall colostrum quality are considered, only $23 \%(\mathrm{n}=55)$ of samples met these recommendations. This proportion was less than that in the study by Morrill et al. (2012), in which $39.4 \%$ of samples met industry standards.

These findings demonstrate that a large number of calves are at risk of receiving colostrum of poor quality, which may interfere with the acquisition of TPI. It also demonstrates that a potentially large number of calves may be exposed to a variety of infectious agents early on in life with a possible impact on health.

Some debate exists about the effects of freezing on the viability of pathogens (Bashandy and Heider, 1979; Pankey et al., 1987; Schukken et al., 1989; Murdough et al., 1996; Sol et al., 2002). Freezing may negatively affect some bacterial species found in colostrum (Fecteau et al., 2002), such as Escherichia coli and Streptococcus dysgalactiae (Pankey et al., 1987), may then affect the overall bacterial counts obtained. A potential limitation of the study design is that the colostrum samples were frozen before culture. As a result, our study may be conservative and underestimate the proportion of colostrum not meeting industry standards.

\section{Modeling to Identify Risk Factors for Colostrum with High Bacterial Load}

The explanatory variables and their association with TPC of $<100,000 \mathrm{cfu} / \mathrm{mL}$ that remained after screening $(P<0.25)$ and were selected for multivariable modeling are outlined in Table 2. The following variables were not associated $(P>0.25)$ with TPC of $<100,000$ $\mathrm{cfu} / \mathrm{mL}$ and were excluded from multivariable model-

Table 2. Counts and percentages of samples for total plate count (TPC) concentrations $<100,000 \mathrm{cfu} / \mathrm{mL}$ and the associations between the outcome variable of TPC $<100,000 \mathrm{cfu} / \mathrm{mL}$ and 11 explanatory variables $(P<0.25)$ that were retained for mixed effects logistic regression modeling

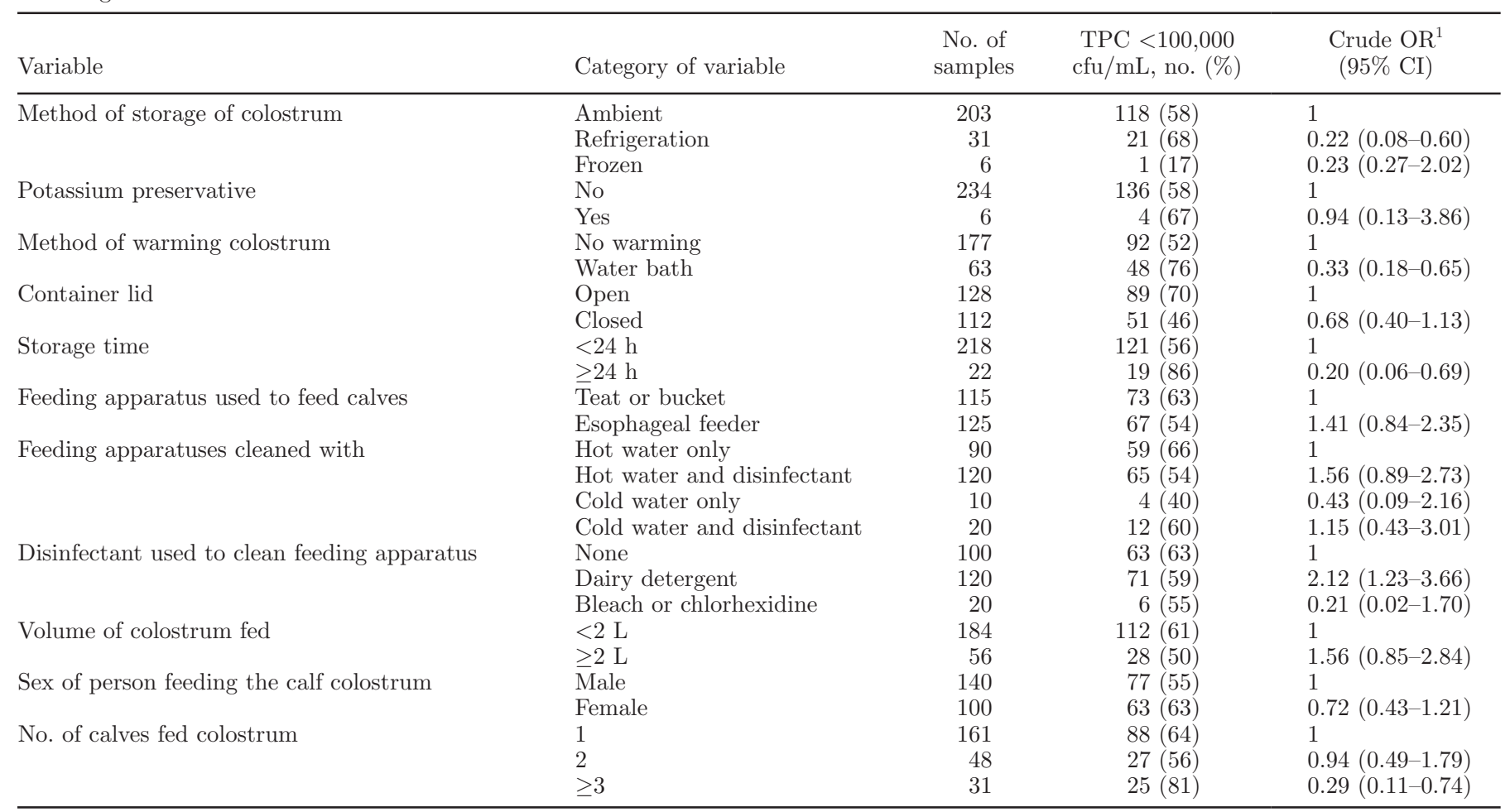

${ }^{1} \mathrm{OR}=$ odds ratio. 
Table 3. Estimated regression coefficients (and SE) from the mixed effects logistic regression model of the factors associated with total plate counts (TPC) exceeding industry recommendations in colostrum samples being fed to replacement dairy heifer calves

\begin{tabular}{|c|c|c|c|c|c|}
\hline Variable & $\begin{array}{l}\text { Samples } \\
\text { (no.) }\end{array}$ & $\begin{array}{c}\text { TPC }<100,000 \\
\text { cfu/mL (no.) }\end{array}$ & $\begin{array}{l}\text { Coefficient } \\
\quad(\mathrm{SE})\end{array}$ & $P$-value & $\begin{array}{l}\text { Odds ratio } \\
(95 \% \text { CI })\end{array}$ \\
\hline Intercept & 240 & 100 & $0.1237(0.3454)$ & 0.720 & - \\
\hline Refrigeration & 31 & 21 & $-1.6347(0.6049)$ & 0.007 & $0.19(0.06-0.64)^{1}$ \\
\hline Frozen & 6 & 1 & $0.1147(1.5532)$ & 0.941 & $1.12(0.05-23.0)$ \\
\hline \multicolumn{6}{|c|}{ Disinfectant used to clean feeding apparatus } \\
\hline Bleach or chlorhexidine & 20 & 6 & $-2.910(1.198)$ & 0.015 & $0.054(0.01-0.57)$ \\
\hline \multicolumn{6}{|l|}{ No. of calves fed colostrum } \\
\hline 1 & 160 & 88 & Referent & & 1.00 \\
\hline 2 & 48 & 27 & $-0.1531(0.4225)$ & 0.717 & $0.85(0.37-1.96)$ \\
\hline$\geq 3$ & 32 & 25 & $-1.7439(0.5611)$ & 0.002 & $0.17(0.06-0.52)$ \\
\hline Random effect ${ }^{2}$ & Variance & $\mathrm{SE}$ & & & \\
\hline
\end{tabular}

${ }^{1}$ Interpretation: After adjusting for the effect of disinfectant used to clean feeding apparatus, number of calves fed colostrum, and unmeasured herd- and sample-level effects, the odds of colostrum being stored in refrigeration exceeding the industry recommendation for TPC was 0.19 (95\% CI: 0.06-0.64) times that of colostrum samples stored at ambient temperature.

${ }^{2}$ Variance and standard error of the variance of the random effect terms.

ing: container used to store colostrum; how often the feeding apparatus was cleaned; pooling of colostrum; source of colostrum; and person responsible for feeding the calf or calves colostrum.

From the candidate explanatory variables examined for associations with TCC of $<10,000 \mathrm{cfu} / \mathrm{mL}$, none remained after screening $(P<0.25)$ and thus multivariable modeling was not undertaken.

Estimated regression coefficients and their standard errors from the mixed effects logistic regression model of the factors associated with TPC exceeding industry recommendations in colostrum samples being fed to replacement dairy heifer calves are shown in Table 3. The importance of the variables selected for modeling are discussed in the following sections.

\section{Colostrum Storage Method and Storage Duration}

The descriptive data relating to storage methods of colostrum are outlined in Table 4. In this study, the majority $(85 \%)$ of colostrum samples fed to calves were stored at ambient temperature. An Australian study by Vogels et al. (2013) also found that it was common practice for herds to store colostrum at ambient room temperature in the dairy (71\%) before feeding to calves.

In the assessment of the overall association of the method of storage of colostrum and the TPC and TCC outcomes, the variable "method of storage of colostrum" was significant at the univariable level $(P=0.003$, Table 2) for TPC. It was retained for mixed effects logistic regression modeling, and it remained significant $(P=0.007$, Table 3$)$. After adjustment for the effect of disinfectant used to clean the feeding apparatus, number of calves fed colostrum, and unmeasured herdlevel effects, colostrum stored under refrigeration had an odds of 0.20 (95\% CI: 0.06-0.64) of exceeding the industry recommendation for the TPC, compared with colostrum samples stored at ambient temperatures.

The method of storage also influenced the length of time for which the colostrum sample was stored and the Brix refractometer reading (Tables 4). This result suggests that some of the farmers and farm staff were

Table 4. Descriptive statistics of duration of storage and Brix percentage for 240 colostrum samples, stratified by storage method

\begin{tabular}{|c|c|c|c|c|c|}
\hline \multirow[b]{2}{*}{ Storage method } & \multirow[b]{2}{*}{ No. $(\%)$} & \multicolumn{2}{|c|}{ Duration of storage $(\mathrm{h})$} & \multicolumn{2}{|c|}{$\operatorname{Brix}(\%)$} \\
\hline & & Mean (SD) & Range & Mean (SD) & Range \\
\hline Ambient & $203(85)$ & $4(13)$ & $0.1-144$ & $20(5)$ & $11-32$ \\
\hline Refrigeration & $31(13)$ & $29(20)$ & $13-97$ & $23(5)$ & $12-33$ \\
\hline Frozen & $6(2)$ & $274(474)$ & $12-1,224$ & $26(4)$ & $21-32$ \\
\hline Total & 240 & $14(82)$ & $0.1-1,224$ & $21(5)$ & $11-33$ \\
\hline
\end{tabular}


selecting colostrum of higher Brix refractometer readings to be stored for supplementing replacement heifer calves at a later date.

In the assessment of the length of time colostrum samples were stored, as a binary variable of $<24 \mathrm{~h}$ and $\geq 24 \mathrm{~h}, 56 \%$ and $86 \%$ (Table 2) of samples met industry standards in terms of TPC of $<100,000 \mathrm{cfu} / \mathrm{mL}$, respectively. The difference was significant at the univariable level $(P=0.001$, Table 2$)$, with colostrum stored for $\geq 24 \mathrm{~h}$ having less than half the odds of having a TPC of $>100,000 \mathrm{cfu} / \mathrm{mL}$. However, the effect was not significant after completing the multivariable models $(P$ $>0.05$ ), and it was therefore excluded from the model. The univariable result may be expected when considering the method of storage in this study because the majority of the samples stored less than $24 \mathrm{~h}$ were from colostrum stored at ambient temperatures and most of the samples stored for greater than $24 \mathrm{~h}$ were from colostrum stored under refrigeration or frozen. Sixty-eight percent of colostrum samples stored under refrigeration and $58 \%$ of colostrum samples stored at ambient temperatures met the industry recommendation of a TPC (Table 2). This finding is supported by Stewart et al. (2005), who found that bacteria multiplied rapidly in colostrum that is stored at warm ambient temperatures and that refrigeration of colostrum samples slows bacterial proliferation. If colostrum is not fed to calves shortly after collection $(<1 \mathrm{~h})$, the recommendation is that it should be cooled rapidly by refrigeration in sanitized, covered containers or frozen in clean containers or bags within $1 \mathrm{~h}$ of harvesting (Godden, 2008, 2009). If colostrum is refrigerated without a preservative such as potassium sorbate, the immunoglobulins and cellular components are maintained for up to 1 week (Manoher et al., 1997). However, colostrum should be fed to calves within 1 to $2 \mathrm{~d}$ because the bacterial counts rise after this point (Stewart et al., 2005). If refrigerated colostrum is treated with a preservative such as potassium sorbate for microbial control, it may be kept for up to $4 \mathrm{~d}$ before being fed to calves (Stewart et al., 2005). Freezing colostrum immediately after collection reduces the bacterial load on colostrum and preserves nutritional and immunoglobulin content; however, it reduces the cellular components of the colostrum source (Foley and Otterby, 1978; Manoher et al., 1997).

Duration of colostrum storage $(<24 \mathrm{~h}$ and $\geq 24 \mathrm{~h})$ and its association with colostral TCC levels were not significant at the univariable level $(P>0.05)$. Only $67 \%$ of the colostrum samples that were frozen before feeding met the industry recommendation for TCC of $<10,000 \mathrm{cfu} / \mathrm{mL}$. In comparison with colostrum samples that were stored at ambient temperature or under refrigeration, a higher percentage, $95 \%$ and $87 \%$, respectively, met the industry recommendations. This finding may require further investigation because only a small number of colostrum samples were frozen before feeding $(\mathrm{n}=6)$, and the result may be directly related to the harvesting of the sample rather than the storage method.

\section{Container Type}

In the current study, we hypothesized that stainless steel containers may be easier to clean on-farm compared with plastic containers and are less likely to harbor bacteria that could contaminate the colostrum during harvest and storage. Sixty-five percent of colostrum samples that were stored in plastic containers met the TPC recommendation, whereas only $38 \%$ of colostrum samples stored in stainless steel containers met the industry recommendations. This result may be due to the stainless steel containers being test buckets that are commonly used to collect milk from sick and mastitic animals. Further, all colostrum samples in stainless steel containers were stored under ambient temperatures. Therefore, the containers may harbor bacteria if the container was previously used to collect milk from a sick or mastitic animal. In addition, colostrum being stored at ambient temperatures allows for greater bacterial proliferation compared with colostrum being stored under refrigeration (Stewart et al., 2005). Further research is required to investigate this finding.

The difference between the container type used to store colostrum was not significant at the univariable level $(P>0.05)$. The variable "container type" $(P=$ 0.138 ) was retained for mixed effect logistic regression modeling for TPC outcome. However, the variable was not significant $(P>0.05)$, and it was removed from the final model.

In the current study, an unexpected result was that $70 \%$ colostrum samples stored without a lid met TPC recommendations, and only $46 \%$ of colostrum samples stored with a lid met industry recommendations. This result may be an effect of duration of storage. The colostrum samples that were stored without a lid were stored for $7 \mathrm{~h}$ on average, and the colostrum samples that were stored with a lid were stored for $22 \mathrm{~h}$ on average. Samples stored for an extended period can undergo further bacterial proliferation (Stewart et al., 2005). The difference between storage of colostrum with or without a lid was significant at the univariable level $(P<0.05)$. However, the variable "container lid" did not remain significant in the mixed effects logistic regression model.

Limited research exists to be drawn on that has examined the container type, with or without a lid, being used to store bovine colostrum and the effect it may have on colostrum quality and bacterial load. A 
study by Manoher et al. (1996) compared the effect of storage on expressed colostrum (from women) kept at room and refrigeration temperatures in steel and plastic containers. Manoher et al. (1996) concluded that colostrum should be stored at $4^{\circ} \mathrm{C}$ in plastic (polypropylene) containers to maintain quality and cellularity. However, this study did not assess bacterial loads on colostrum. Comparing practices in the study conducted by Manoher et al. (1996) to on-farm practices maybe difficult because the sanitization standards carried out in a hospital setting would presumably be greater than in a commercial dairy herd setting.

Several researchers have recommended that colostrum be stored in covered plastic containers to reduce further bacterial contamination and reduce the rate of bacterial regrowth during storage (particularly for colostrum stored at ambient temperature and refrigeration; McGuirk and Collins, 2004; Godden, 2009).

\section{Artificial Feeding of Colostrum}

The source of colostrum that was being fed to the calves on the farm varied. Colostrum fed to a calf that was from a cow other than its dam had a greater percentage of samples meeting combined recommendations for TPC, TCC, and Brix refractometer reading (33\%) compared with colostrum samples from the calf's dam and from an unknown source, $8 \%$ and $23 \%$, respectively. However, the overall association of source of colostrum and TPC outcome and TCC outcome were not significant at the univariable level $(P>0.05)$.

Twenty percent of samples in the study were from a pooled source with only $52 \%$ of the pooled colostrum samples meeting the industry recommended TPC, whereas $60 \%$ of nonpooled colostrum samples met the industry recommended TPC. However, when the industry recommendations for TPC, TCC, and the Brix refractometer reading of $\geq 22 \%$ were considered, no difference existed between the nonpooled and pooled samples with $23 \%$ and $22 \%$, respectively, meeting these industry recommendations. The overall association of whether the colostrum was pooled or not and TPC and TCC outcome was not significant at the univariable level $(P>0.05)$.

When $\leq 2$ L of colostrum was fed, $61 \%$ of colostrum samples met industry standards for TPC and TCC compared with $48 \%$ of colostrum samples when $>2$ $\mathrm{L}$ was fed. The overall association of volume fed and TPC outcome was not significant at the univariable level $(P=0.150$, Table 2$)$. Although this variable was retained for mixed effect logistic regression modeling, the variable was not significant and was removed from the model.
In an assessment of the method of feeding of colostrum in terms of meeting industry standards of TPC, TCC, and Brix refractometer reading, the percentage of samples meeting the recommendations was equal: $23 \%$ of samples from teat/bucket and $23 \%$ of samples from an esophageal feeder (Table 2). When the variable "apparatus used for feeding the calf or calves" was assessed for it associations with the TPC outcome, it was not significant at the univariable level $(P=0.20)$.

In the current study, feeding multiple calves with colostrum from a single source was common (average of 1.56 calves fed from single source of colostrum). The current industry recommendation is to use the rule of "one cow to one calf" to limit the infectious agent exposure risk to only one calf instead of multiple calves (Godden, 2015). This practice may not be practical on less intensively managed Australian dairy farms or when high-quality colostrum supplies are limited.

On many dairy farms, whatever colostrum is available at the time, whether it is from the dam or another freshly calved cow in the herd, is likely the one fed to replacement dairy calves for their first feed (Phipps, 2016). We suggest that only colostrum of high quality and likely to have a low bacterial load should be used to feed calves, regardless of its origin. However, the practice of pooling raw colostrum is not recommended because it may reduce the immunoglobulin concentration of the colostrum, and it may increase the risk of spreading or exposing neonatal calves to colostrumborne infectious agents (Godden, 2008). Consequently, the recommended rule of one cow to one calf (Godden, 2015) is widely adopted for North American dairy herds (Trotz-Williams et al., 2008; Beam et al., 2009), and carrying it out on Australian dairy farms is advised.

\section{Colostrum Feeding Hygiene}

In the univariable analysis, how often the feeding apparatus was cleaned was not significantly $(P>0.05)$ associated with TPC and TCC. However, the disinfectant used to clean the feeding apparatus was significantly $(P$ $<0.05)$ associated with the TPC outcome. The variable was retained for the mixed effect logistic regression modeling and was found to be significant $(P=0.015$, Table 3). Colostrum samples fed using a calf feeding apparatus that was cleaned with chlorhexidine gluconate or bleach before use had odds of 0.054 (95\% CI: 0.01-0.57) of exceeding the industry recommendation for TPC compared with colostrum fed in a calf feeding apparatus that was cleaned with no disinfectant (Table 3). Therefore, from the findings in the current study, cleaning the feeding apparatus with chlorhexidine gluconate or bleach after feeding each calf is recommended. 


\section{Number of Calves Being Fed Colostrum}

A total of 384 calves were fed colostrum from the collected colostrum samples. The average number of calves fed colostrum from a single source was 1.56 (median 2; range 1-10). No difference was found in the colostrum Brix refractometer reading as the number of calves being fed colostrum increased. The average volume of colostrum being fed to calves was $2.36 \mathrm{~L}$ (median $2 \mathrm{~L}$; range 1-4 L). The breed of calves in the study included Holstein Friesian $(\mathrm{n}=241)$, Jersey $(\mathrm{n}=51)$, Holstein Friesian $\times$ Jersey $(\mathrm{n}=33)$, other crossbreed calves (Australian Red, Ayrshire, Illawarra Red, and their crosses; $\mathrm{n}=56$ ), and other purebreds (Illawarra Red; $\mathrm{n}=3$ ). On average, other purebred calves (Illawarra Red) received colostrum that had a significantly $(P \leq$ 0.05) lower Brix refractometer reading compared with calves in either the Holstein Friesian, Jersey, Holstein Friesian $\times$ Jersey, or other cross-breed groups.

In the current study, the variable "number of calves fed colostrum on the day of colostrum sampling" was assessed in the univariable analysis for an association with TPC outcome and was found to be significant $(P$ $=0.01$, Table 2 ). This variable was retained for the mixed effect logistic regression modeling and was found to be significant ( $P=0.002$, Table 3$)$. Colostrum being fed to a calf on farms where 3 or more calves were fed colostrum on the day of sampling was associated with an odds of 0.17 (95\% CI: 0.058-0.52) of exceeding the industry recommendation for the TPC compared with colostrum being fed to a single calf in a day. This result suggests a relationship exists between herd size $(<300$ cows and $\geq 300$ cows) and number of calves fed on the day of colostrum sampling $(1,2$, or $\geq 3)$, with a higher proportion of samples on larger dairy farms $(\geq 300$ cows) that fed 3 or more calves on the day of colostrum sampling meeting the TPC recommendations. Larger dairy herds that feed more than 3 calves' colostrum per day may pay greater attention to hygiene of colostrum than smaller herds. This hypothesis is supported by the findings that dairy herds with $\geq 300$ cows had a higher proportion of samples meeting the industry recommendations for the TPC and TCC as well as TPC, TCC, and Brix refractometer reading combined.

\section{Person Responsible for Feeding Colostrum}

The person responsible for feeding the colostrum and the sex of that person was assessed for association with TPC and TCC outcomes. The overall associations of the variables were not significant at the univariable level $(P$ $>0.05)$. Therefore, regardless of sex and the employment position of the person responsible for feeding the calves colostrum (dairy herd owner or staff member), no effect on the outcome of colostrum in terms of TPC and TCC was present.

\section{Herd Size}

Herds with $>300$ cows had a higher percentage of samples meeting industry colostrum recommendations compared with herds of $<300$ cows. The percentage of colostrum samples in dairy herds with $<300$ cows that met the recommendations for TPC, TCC, and TPC, TCC and Brix refractometer readings combined were 50,92 , and $8 \%$, respectively. The percentage of colostrum samples in dairy herds with $\geq 300$ cows that met the 3 industry recommendations were 64,94 , and $34 \%$, respectively.

The prediction intervals for the herd-level random effects model for the TPC are plotted in increasing order in Figure 2. This plot shows the variability in unmeasured herd-level effects on TPC. In addition, the plot ranks the herds in terms of how they performed in regards to colostrum samples with TPC exceeding the industry recommendations. That is, herds in which the random effect terms approaches 1 (shown on the right hand side of the plot) were more likely to have a high proportion of colostrum samples with a TPC exceeding industry recommendations compared with herds with random effect terms less than 0 , after adjusting for the fixed effects included in the model (i.e., storage method, the way feeding apparatus was cleaned, and the number of calves fed colostrum on the day of sampling). A potentially useful area of future research would be to carry out detailed investigations of the "far-left" and "far-right" herds to more precisely define herd-level management characteristics contributing to the probability of TPCs exceeding industry recommendations.

\section{CONCLUSIONS}

In the herds that were studied, $58 \%$ of colostrum samples met the recommended industry standard of a TPC of $<100,000 \mathrm{cfu} / \mathrm{mL}$ and $94 \%$ of colostrum samples met the recommended industry standard of TCC of $<10,000 \mathrm{cfu} / \mathrm{mL}$. However, when the current industry recommendations in terms of TPC, TCC, and Brix refractometer reading for colostrum quality were considered, only $23 \%$ of samples met all these standards. These findings demonstrate that a large number of calves were at risk of receiving colostrum of suboptimal quality and thus at increased risk of failure of passive transfer. These calves were exposed to colostrum that contained bacterial loads at levels high enough to interfere with the acquisition of TPI and to affect calf health. When the process of harvesting and management of colostrum is assessed, many farm- 


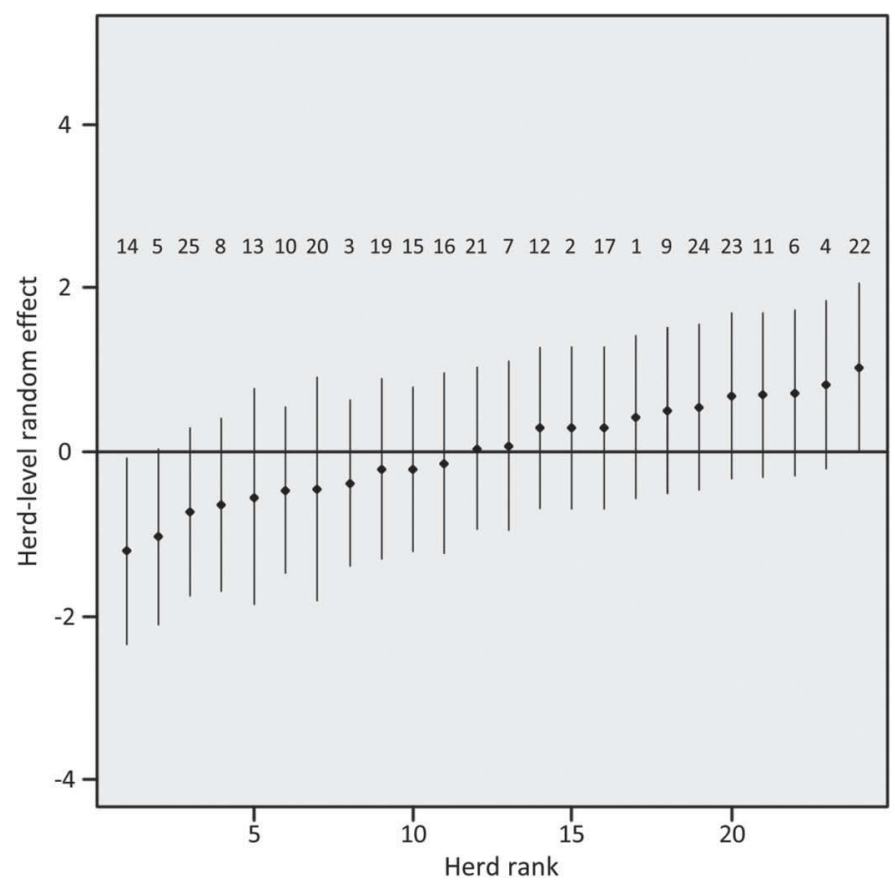

Figure 2. Caterpillar plot of the total plate count of each of the 24 individual farms enrolled in the study $(95 \% \mathrm{CI}=$ thin line). The number above the data point refers to the individual herd number.

specific factors are likely present that may influence the level of bacterial contamination of colostrum. Further investigation is required to identify these farm-specific factors. Recommendations as a result of this study include refrigeration of excess colostrum shortly (within $1 \mathrm{~h}$ ) after collection and thorough disinfection of the calf feeding apparatus (e.g., chlorhexidine gluconate or bleach) before use.

\section{ACKNOWLEDGMENTS}

The study was supported by the Rochester Veterinary Practice (Rochester, Australia), Dairy Australia (Southbank, Australia), Gardiner Foundation (Melbourne, Australia), and the University of Melbourne (Melbourne, Australia) and funded by Greenhams Pty Ltd. (Tongala, Australia). The authors thank the Gribbles Veterinary Pathology for performing the bacteriological assessment and the participating farmers their assistance and involvement in this research.

\section{REFERENCES}

Arthington, J. D., M. B. Cattell, J. D. Quigley, G. C. McCoy, and W. L. Hurley. 2000. Passive immunoglobulin transfer in newborn calves fed colostrum or spray-dried serum protein alone or as a supplement to colostrum of varying quality. J. Dairy Sci. 83:28342838 .
Bartier, A. L., M. C. Windeyer, and L. Doepel. 2015. Evaluation of on-farm tools for colostrum quality measurement. J. Dairy Sci. 98:1878-1884.

Bashandy, E. Y., and L. E. Heider. 1979. The effect of freezing of milk samples on the cultural results. Zentralbl. Veterinarmed. B 26:1-6.

Beam, A. L., J. E. Lombard, C. A. Kopral, L. P. Garber, A. L. Winter, J. A. Hicks, and J. L. Schlater. 2009. Prevalence of failure of passive transfer of immunity in newborn heifer calves and associated management practices on US dairy operations. J. Dairy Sci. 92:3973-3980.

Bielmann, V., J. Gillan, N. Perkins, A. Skidmore, S. Godden, and K. Leslie. 2010. An evaluation of Brix refractometry instruments for measurement of colostrum quality in dairy cattle. J. Dairy Sci. 93:3713-3721.

Bush, L. J., and T. Staley. 1980. Absorption of colostral immunoglobulins in newborn calves. J. Dairy Sci. 63:672-680.

Dairy Australia. 2011. Rearing Healthy Calves: How to raise calves that thrive. Dairy Australia Ltd., Southbank, Australia.

DeNise, S. K., J. D. Robison, G. H. Stott, and D. V. Armstrong. 1989. Effects of passive immunity on subsequent production in dairy heifers. J. Dairy Sci. 72:552-554.

Dinsmore, P., and A. Skidmore. 2008. Comparison of Brix (sugar) refractometer and colostrometer for evaluation of colostrum quality in dairy cows. J. Dairy Sci. 91:355. (Abstr.)

Donovan, G. A., I. R. Dohoo, D. M. Montgomery, and F. L. Bennett. 1998. Associations between passive immunity and morbidity and mortality in dairy heifers in Florida, USA. Prev. Vet. Med. 34:31-46.

Elizondo-Salazar, J. A., and A. J. Heinrichs. 2009. Feeding heat-treated colostrum or unheated colostrum with two different bacterial concentrations to neonatal dairy calves. J. Dairy Sci. 92:4565-4571.

Faber, S. N., N. E. Faber, T. C. McCauley, and R. L. Ax. 2005. Case study: Effects of colostrum ingestion on lactational performance. Prof. Anim. Sci. 21:420-425.

Fecteau, G., P. Baillargeon, R. Higgins, J. Paré, and M. Fortin. 2002. Bacterial contamination of colostrum fed to newborn calves in Québec dairy herds. Can. Vet. J. 43:523-527.

Foley, J. A., and D. E. Otterby. 1978. Availability, storage, treatment, composition, and feeding value of surplus colostrum: A review. J. Dairy Sci. 61:1033-1060.

Godden, S. 2008. Colostrum management for dairy calves. Vet. Clin. North Am. Food Anim. Pract. 24:19-39.

Godden, S. M. 2009. Microbial hazards associated with feeding colostrum. Accessed Dec. 5, 2015. http://www.dairyweb.ca/Resources/ SWNMC2009/Godden.pdf.

Godden, S. 2015. "No bugs please"- - How to feed clean colostrum to baby calves. Accessed Dec 5, 2015. http://www.extension.umn. edu/agriculture/dairy/calves-and-heifers/no-bugs-please/.

James, R. E., and C. E. Polan. 1978. Effect of orally administered duodenal fluid on serum proteins in neonatal calves. J. Dairy Sci. 61:1444-1449.

James, R. E., C. E. Polan, and K. A. Cummins. 1981. Influence of administered indigenous microorganisms on uptake of [iodine-125] $\gamma$-globulin in vivo by intestinal segments of neonatal calves. J. Dairy Sci. 64:52-61.

James, R. E., C. E. Polan, and D. Zanartu. 1977. Effect of orally administered duodenal fluid on serum gamma globulin levels in neonatal calves. J. Dairy Sci. 60(Suppl. 1):168. (Abstr.)

Johnson, J. L., S. M. Godden, T. Molitor, T. Ames, and D. Hagman. 2007. Effects of feeding heat-treated colostrum on passive transfer of immune and nutritional parameters in neonatal dairy calves. J. Dairy Sci. 90:5189-5198.

Manoher, A. A., M. Williamson, and G. V. Kappikar. 1996. Effects of storage of colostrum in various containers. Indian Pediatr. 34:293296.

McGuirk, S. M., and M. Collins. 2004. Managing the production, storage, and delivery of colostrum. Vet. Clin. North Am. Food Anim. Pract. 20:593-603.

Morrill, K. M., E. Conrad, A. Lago, J. Campbell, J. Quigley, and H. Tyler. 2012. Nationwide evaluation of quality and composition 
of colostrum on dairy farms in the United States. J. Dairy Sci. 95:3997-4005.

Morrill, K. M., K. E. Robertson, M. M. Spring, A. L. Robinson, and H. D. Tyler. 2015. Validating a refractometer to evaluate immunoglobulin G concentration in Jersey colostrum and the effect of multiple freeze-thaw cycles on evaluating colostrum quality. J. Dairy Sci. 98:595-601.

Murdough, P. A., K. E. Deitz, and J. W. Pankey. 1996. Effects of freezing on the viability of nine pathogens from quarters with subclinical mastitis. J. Dairy Sci. 79:334-336.

Pankey, J. W., J. K. Wadsworth, K. H. Metha, and P. A. Murdough. 1987. Effects of storage on viability of mastitis pathogens. J. Dairy Sci. 70:132. (Abstr.)

Phipps, A. 2016. Colostrum management practices and effects on colostrum quality on commercial northern Victorian dairy farms. MVSc (Clinical) Thesis. University of Melbourne, Melbourne, Australia.

Poulsen, K. P., F. A. Hartmann, and S. M. McGuirk. 2002. Bacteria in colostrum: Impact on calf health. Page 773 in Proc. 20th American College of Internal Veterinary Medicine, St. Louis, MO. Mira Digital Publishing, Chesterfield, MO.

Quigley, J. D., and J. J. Drewry. 1998. Nutrient and immunity transfer from cow to calf pre-and postcalving. J. Dairy Sci. 81:2779-2790.

Quigley, J. D., A. Lago, C. Chapman, P. Erickson, and J. Polo. 2013. Evaluation of the Brix refractometer to estimate immunoglobulin G concentration in bovine colostrum. J. Dairy Sci. 96:1148-1155.

Robison, J. D., G. H. Stott, and S. K. DeNise. 1988. Effects of passive immunity on growth and survival in the dairy heifer 1,2 . J. Dairy Sci. 71:1283-1287.
Schukken, Y. H., J. A. H. Smit, F. J. Grommers, D. Vandegeer, and A. Brand. 1989. Effect of freezing on bacteriologic culturing of mastitis milk samples. J. Dairy Sci. 72:1900-1906.

Sol, J., O. C. Sampimon, E. Hartman, and H. W. Barkema. 2002. Effect of preculture freezing and incubation on bacteriological isolation from subclinical mastitis samples. Vet. Microbiol. 85:241-249.

StataCorp. 2013. Stata Statistics Software. Release 13. StataCorp LP, College Station, TX.

Staley, T. E., and L. J. Bush. 1985. Receptor mechanisms of the neonatal intestine and their relationship to immunoglobulin absorption and disease 1, 2. J. Dairy Sci. 68:184-205.

Stewart, S., S. Godden, R. Bey, P. Rapnicki, J. Fetrow, R. Farnsworth, M. Scanlon, Y. Arnold, L. Clow, K. Mueller, and C. Ferrouillet. 2005. Preventing bacterial contamination and proliferation during the harvest, storage, and feeding of fresh bovine colostrum. J. Dairy Sci. 88:2571-2578.

Trotz-Williams, L. A., K. E. Leslie, and A. S. Peregrine. 2008. Passive immunity in Ontario dairy calves and investigation of its association with calf management practices. J. Dairy Sci. 91:3840-3849.

Vogels, Z. G. M. Chuck, and J. M. Morton. 2013. Failure of transfer of passive immunity and agammaglobulinaemia in calves in southwest Victorian dairy herds: prevalence and risk factors. Aust. Vet. J. 91:150-158.

Wells, S. J., D. A. Dargatz, and S. L. Ott. 1996. Factors associated with mortality to 21 days of life in dairy heifers in the United States. Prev. Vet. Med. 29:9-19. 